\title{
The effects of market orientation and innovation on competitive advantage and business perfor- mance of textile SMEs
}

\author{
Udriyah $^{a^{*}}$, Jacquline Tham ${ }^{\text {a }}$ and S. M. Ferdous Azam ${ }^{a}$
}

aPost Graduate Centre, Management and Science University, University Drive, Off Persiaran Olahraga, Section 13, 40100, Selangor, Malaysia

\begin{tabular}{|c|c|}
\hline CHRON I C L E & A B S T RACT \\
\hline $\begin{array}{l}\text { Article history: } \\
\text { Received: April 15, } 2019 \\
\text { Received in revised format: April } \\
272019 \\
\text { Accepted: May 11, } 2019 \\
\text { Available online: } \\
\text { May 11,2019 } \\
\text { Keywords: } \\
\text { Market Orientation } \\
\text { Innovation } \\
\text { Competitive Advantage } \\
\text { Business Performance }\end{array}$ & $\begin{array}{l}\text { This paper analyzes the effects of market orientation and innovation on competitive advantage and } \\
\text { business performance. The method of collecting data is a designed questionnaire. The sample size } \\
\text { is } 150 \text { textile SMEs in Selangor, Malaysia. Path analysis by operating SPSS } 20.0 \text { is used in analyz- } \\
\text { ing the research. The result shows that market orientation and innovation had positive and signifi- } \\
\text { cant effects on competitive advantage, partially. Market orientation and innovation give contribu- } \\
\text { tions to the competitive advantage of } 46.3 \% \text { while the rest of } 54.7 \% \text { are influenced by other varia- } \\
\text { bles which are not described in this study. Competitive advantage partially has a positive and sig- } \\
\text { nificant influence on business performance. Market orientation and innovation also have significant } \\
\text { effects on business performance both directly and indirectly through competitive advantage. Mar- } \\
\text { ket orientation, innovation, and competitive advantage give contributions to the business perfor- } \\
\text { mance of } 58.4 \% \text { while the rest of } 41.6 \% \text { are influenced by others variables which are not described } \\
\text { in this study. }\end{array}$ \\
\hline
\end{tabular}

\section{Introduction}

Small and Medium Enterprises (SMEs) is one of the economic indicators of any country. Malaysia is one of the ASEAN countries that pay significant attention to SMEs. However, compared with other industrial countries and developing nations, the contribution of SMEs to the Malaysian economy is relatively low (Amin et al., 2016). According to MITI (2018) "Malaysia stands to gain most in the textile, clothing and footwear sectors, and the leather sector is expected to increase substantially up to $154 \%$ ". Currently, there are 795 textile SMEs in Malaysia (SME Corp Malaysia, 2018). In 2016, the export of textile products was RM 13.9 billion, offer only $1.8 \%$ to Malaysia's total export of manufacturing products (Malaysian Investment Development Authority, MIDA). However, compared with other Southeast Asian countries, Malaysian textile exports are still low, the export value is ranked $6^{\text {th }}$ among other Southeast Asia countries while the textile exports can be improved by increasing competitive advantage and business performance (ASEAN Statistic, 2018). According to Aziz and Samad (2016), SMEs in Malaysia are struggling with various barriers to improve their business units through innovative tasks such as lack of

* Corresponding author.

E-mail address: udriyah22@gmail.com (Udriyah) 
internal funds, inadequate managerial skills, labor skills, etc. Therefore SMEs need to involve in innovation in order to gain a better competitive advantage (Aziz \& Samad, 2016; Suriyapperuma et al., 2015). The literature and the previous studies state that market orientation and innovation influence the competitive advantages and business performance of SMEs.

\section{Review of the Literature}

This section provides a literature review of some theories. The literature consists of definitions and dimensions of market orientation, innovation, competitive advantage, and business performance. The linkage and hypothesis also provided in this section.

\subsection{Market Orientation}

According to Maydeu-olivares and Lado (2003), market orientation can be defined as company's method to create superior performance and the behaviors needed to improve the performance of the firm. The performance can be accomplished by applying a market-oriented culture, that is how the company understands the needs, wants and demands of the market (Andriyanto \& Sufian, 2017). The market orientation dimensions are customer orientation, competitor orientation, and inter-functional coordination (Narver \& Slater, 1990; Azam et al., 2014; Tham et al., 2017).

\subsection{Innovation}

Innovation is a process to turn an opportunity into a marketable idea (Reniati, 2013). According to Saunila (2014), SMEs may receive even more benefit if they develop, communicate, embrace and explore the innovation orientation. Innovation dimensions that consist of product innovation, process innovation, market innovation were investigated thoroughly by Rosli and Sidek (2013) and in this study we use the items from this study. SMEs can obtain even more advantage if SMEs develop, communicate, twine and get the innovation orientation (Aziz, \& Samad, 2016; Ismail \& Tarofder, 2015).

\subsection{Competitive Advantage}

Competitive advantage can be defined as the aggregation of various items which differentiates SMEs from their competitors and provides a unique and superior position in the market. The competitive advantage dimensions (innovation, differentiation, and low-cost leadership) were adapted from Afsharghasemi et al. (2013) for the proposed study of this paper.

Narver and Slater (1990) argue that market orientation must be the prevalent focus of the whole enterprise to steadily create excellent value for the customers, and accordingly can gain a sustainable competitive advantage. Talaja et al. (2017) stated that market orientation improves competitive advantage that consequently escalates the business performance of an enterprise. There is a positive interaction between market orientation and competitive advantage, (Zhou et al., 2009; Kamya et al., 2010; Safarnia et al., 2011; Herman et al., 2018) even among manufacturing SMEs in Malaysia (Afsharghasemi, 2013). Therefore, the we consider the following hypothesis:

$\mathrm{H}_{1}$ : Market orientation (MO) positively influences on competitive advantage (CA) of textile SMEs in Selangor, Malaysia.

Aziz and Samad (2016) argue that the SMEs ought to entangle in innovation in order to obtain a competitive advantage in the marketplace. Several studies found a positive relationship between innovation and competitive advantage (Wingwon, 2012; Bulankulama \& Khatibi, 2014; Vazquez-avila, 2014; Aziz \& Samad, 2016; Kamboj \& Rahman, 2017; Herman et al., 2018). So the hypothesis is:

$\mathrm{H}_{2}$ : Innovation (IN) positively influences on competitive advantage (CA) of textile SMEs in Selangor, Malaysia. 


\subsection{Business Performance}

According to Smith and Reece (1999), "Business performance is defined as the operational ability to satisfy the desires of the company's major shareholders, and it must be assessed to measure an organization's accomplishment". There are various methods to measure business performance of enterprises since performance is multidimensional that related to the subject of interest (Rahman et al., 2018). Business performance dimensions in this research are the market performance, supplier performance, process performance, people performance, and customer relationship performance (Nur et al., 2011). SMEs need to understand the concept of market orientation that can provide performance benefits to the SMEs (Amin et al., 2016). There is a significant relationship between market orientation and business performance (Dubihlela \& Sandada, 2014; Śályová et al., 2015; Lee et al., 2015; Amin et al., 2016) directly and/or indirectly (Buli, 2017; Herman et al., 2018). Therefore, we proposed the following hypothesis:

$\mathrm{H}_{3}$ : Market orientation (MO) has a positive influence on business performance (BP) of textile SMEs in Selangor, Malaysia.

According to Amin et al. (2016), Firms with innovative capacity and collective capability will more likely to promote their performance. SMEs are proposed to focus over on refinements in innovativeness to jack up SMEs' performance. Innovation contributes to firm performance (Vazquez-avila, 2014). There is a significant positive relationship between innovation and business performance (Najib \& Kiminami, 2011; Saunila, 2014; Vazquez-avila., 2014; Herman et al., 2018).

$\mathrm{H}_{4}$ : Innovation (IN) has a positive influence on business performance (BP) of textile SMEs in Selangor, Malaysia.

Competitive advantage can be considered as a partial mediator in the relationship between market orientation and business performance (Talaja, 2017), which means there is a relationship between competitive advantage and business performance (Lakhal, 2009; Agha et al., 2011; Monsur \& Yoshi, 2012; Suriyapperuma et al., 2015). Competitive advantage is the mediating variable between market orientation and product innovation toward SMEs performance, and competitive advantage positively influence SMEs performance (Herman et al., 2018). Based on the explanation above so the hypothesis is:

$\mathrm{H}_{5}$ : Competitive advantage (CA) has a positive influence on business performance (BP) of textile SMEs in Selangor, Malaysia.

\section{Materials and Methods}

This section explains the research methodology used in this research. This section consists of the research design process, data collection method, population and sample of the research, and research instrument development.

\subsection{Research Design Process}

In general, "research design is a blueprint or plan for the collection, measurement, and analysis of data" (Sekaran \& Bougie, 2016). This research uses a deductive approach with positivism research paradigm, which is based on the theory and proven by previous researches to ensure the truth of the research. This research uses the survey method with the questionnaire approach.

\subsection{Data Collection Method}

The primary type of data used in this research is quantitative data, and are obtained using a questionnaire. The questionnaire is a data collection tool in the form of a series of written questions submitted to respondents to get answers in a written form. The questionnaire are distributed by using two ways, through physically directing distribution, and electronic methods by e-mail or Google document.

\subsection{Population and Sample}


The population of this study includes all textile 233 SMEs in Selangor, Malaysia (August 2018 period). Unit of analysis of this study is the owner or manager of textile SMEs. This research uses nonprobability sampling and specific sampling technique used is based on convenience sampling to take the samples. To determine the sample size in this study we have used Slovin formula where the population is 233, by $5 \%$ of confidence level and the sample size is calculated as 150 SMEs.

\subsection{Research Instrument Development}

The questionnaire is the instrument used in this study. The questionnaire consists of two parts. The first part is associated with the respondent's profiles which consist of six items. In the second part, a five-point Likert scale has been used to measure the 15 items of market orientation, 15 items of innovation, 15 items of competitive advantage, and 25 items of business performance. Validity and reliability tests have been used to ensure the validity and reliability of the questionnaire. To test the model, this study used the path analysis approach, and SPSS 20.0 has been used to analyze the data. Furthermore, several standard assumption tests have been accomplished such as normality test, multicollinearity test, and heteroskedasticity test to make sure the data is fit to be processed.

\section{Analysis and Findings}

This section explains all of the findings of the research. This section consists of the demographic profile of the respondents, descriptive analysis of variables, hypothesis path analysis, and also hypothesis test.

\subsection{Demographic Profile}

The respondents are the owners or managers of the textile SMEs. The profile of respondents consists of gender, age, position in the SMEs, age of SMEs, number of employees, and sales turnover of SMEs as shown Table 1 and Table 2.

Table 1

Demographic of SMEs

\begin{tabular}{clcc}
\hline Demographic & $\begin{array}{c}\text { Frequenc } \\
\text { y }\end{array}$ & Percentage \\
\hline \multirow{2}{*}{ Age of } & $<1$ year & 13 & $8.7 \%$ \\
SMEs & $1-5$ years & 76 & $50.7 \%$ \\
& $>5$ years & 61 & $40.7 \%$ \\
\hline \multirow{2}{*}{ Number of } & $<5$ & 44 & $29.3 \%$ \\
Employees & $5-75$ & 78 & $52.0 \%$ \\
& $75-200$ & 28 & $18.7 \%$ \\
\hline \multirow{5}{*}{ Sales } & $<$ RM 300,000 & 61 & $40.7 \%$ \\
Turnover & RM 300,000 - & 77 & $51.3 \%$ \\
& RM 15 M & & \\
& RM 15 -50 & 12 & $8.0 \%$ \\
\hline
\end{tabular}

Source: Processed primary data from SPSS, 2018
Table 2

Demographic of Owner/Manager

\begin{tabular}{clcc}
\hline \multicolumn{2}{l}{ Demographic } & $\begin{array}{c}\text { Frequenc } \\
\text { y }\end{array}$ & Percentage \\
\hline \multirow{2}{*}{ Gender } & Male & 69 & $46 \%$ \\
& Female & 81 & $54 \%$ \\
\hline \multirow{4}{*}{ Age } & $\leq 25$ & 34 & $22.7 \%$ \\
& $26-35$ & 66 & $44.0 \%$ \\
& $36-45$ & 35 & $23.3 \%$ \\
& $46-55$ & 12 & $8.0 \%$ \\
& $\geq 56$ & 3 & $2.0 \%$ \\
\hline \multirow{3}{*}{ Position } & Owner & 100 & $66.7 \%$ \\
& Manager & 50 & $33.3 \%$ \\
\hline
\end{tabular}

Source: Processed primary data from SPSS, 2018

\subsection{Descriptive Analysis}

Descriptive analysis has been used to analyze and learn about the general description of the company used as sample research. The average score for market orientation is 3.85 , innovation is 3.82 , competitive advantage is 3.79 , and business performance is 3.87 .

\subsection{Path Analysis}

There are two structural equations for path analysis in this study. Structural equation 1 aims to determine the market orientation and innovation influence toward competitive advantage. Table 3 shows the results of the path analysis. 
Table 3

The results of path analysis for the relationship of market orientation and innovation on business performance

\begin{tabular}{llrrr}
\hline \multirow{2}{*}{ Model } & & \multicolumn{2}{c}{ Unstandardized Coefficients } & \multicolumn{2}{c}{ Standardized Coefficients } \\
\cline { 2 - 5 } 1 & & \multicolumn{1}{c}{ B } & Std. Error & Beta \\
\cline { 2 - 5 } & (Constant) & 13.413 & 3.870 & 0.246 \\
& Market Orientatation & 0.247 & 0.080 & 0.498 \\
\hline
\end{tabular}

\section{Table 4}

The result of determinant Coefficient of the results given in Table 3

\begin{tabular}{lcccc}
\hline Model & $\mathrm{R}$ & $\mathrm{R}$ Square & Adjusted R Square & Std. Error of the Estimate \\
\hline 1 & $.685^{\mathrm{a}}$ & .470 & .463 & 5.151 \\
\hline Source: SPSS 20.0 Output, 2018 & & &
\end{tabular}

Based on the results of Table 4, to calculate the path coefficient we can use the following formula:

$e 1=\sqrt{1-R^{2}}=\sqrt{1-0.470}=0.7280$

and the final results of Table 3 can be represented as $\mathrm{Y}=0.246 \mathrm{X}_{1}+0.498 \mathrm{X}_{2}+0.7280$, where $X_{1}$ and $X_{2}$ and $Y$ represent market orientation, innovation and business performance, respectively.

Structural equation 2 aims to determine the influence of market orientation, innovation and competitive advantages on business performance.

Table 5

The results of Path Analysis for Equation 2

\begin{tabular}{llccc}
\hline \multirow{2}{*}{ Model } & & \multicolumn{2}{c}{ Unstandardized Coefficients } & Standardized Coefficients \\
\cline { 3 - 5 } & & $\mathrm{B}$ & Std. Error & Beta \\
\hline \multirow{2}{*}{1} & (Constant) & 18.997 & 5.378 & 0.285 \\
& Market Orientatation & 0.435 & 0.110 & 0.327 \\
& Innovation & 0.507 & 0.123 & 0.273 \\
\hline
\end{tabular}

Source: SPSS 20.0 Output, 2018

\section{Table 6}

Result of Determinant Coefficient 2

\begin{tabular}{ccccc}
\hline Model & $\mathrm{R}$ & $\mathrm{R}$ Square & Adjusted R Square & Std. Error of the Estimate \\
\hline 1 & $.769^{\mathrm{a}}$ & .592 & .584 & 6.881 \\
\hline Source: SPSS 20.0 Output, 2018 & & &
\end{tabular}

Based on the results of Table 6, we may calculate the path coefficient based on the following formula:

$e 2=\sqrt{1-R^{2}}=\sqrt{1-0.592}=0.6387$

Meanwhile, structural equation 2 can be represented as $Z=0.285 X_{1}+0.327 X_{2}+0.273 Y+0.6387$. The influence structure of Market Orientation and Innovation on Competitive Advantage, and the effect of Market Orientation, Innovation, and Competitive Advantage on Business Performance can be illustrated in Fig. 1. Then, to determine the influence of direct, indirect influence, as well as the path coefficient of each variable we may use Table 7 as follows,

\section{Table 8}

Direct and Indirect Influence

\begin{tabular}{ccccc}
\hline Variable & Path Coefficient & Direct Influence & The Indirect Influence & Total \\
\hline $\mathrm{X} 1 \rightarrow \mathrm{Y}$ & & 0.246 & & 0.246 \\
$\mathrm{X} 2 \rightarrow \mathrm{Y}$ & & 0.498 & 0.498 \\
$\mathrm{Y} \rightarrow \mathrm{Z}$ & & 0.273 & & 0.273 \\
$\mathrm{X} 1 \rightarrow \mathrm{Z}$ & & 0.285 & $0.246 \times 0.273=0.067158$ & 0.352 \\
$\mathrm{X} 2 \rightarrow \mathrm{Z}$ & & 0.327 & $0.498 \times 0.273=0.135954$ & 0.463 \\
$\mathrm{e} 1$ & 0.7280 & & & 0.7280 \\
$\mathrm{e} 2$ & 0.6387 & & & 0.6387 \\
\hline Sour & & & &
\end{tabular}




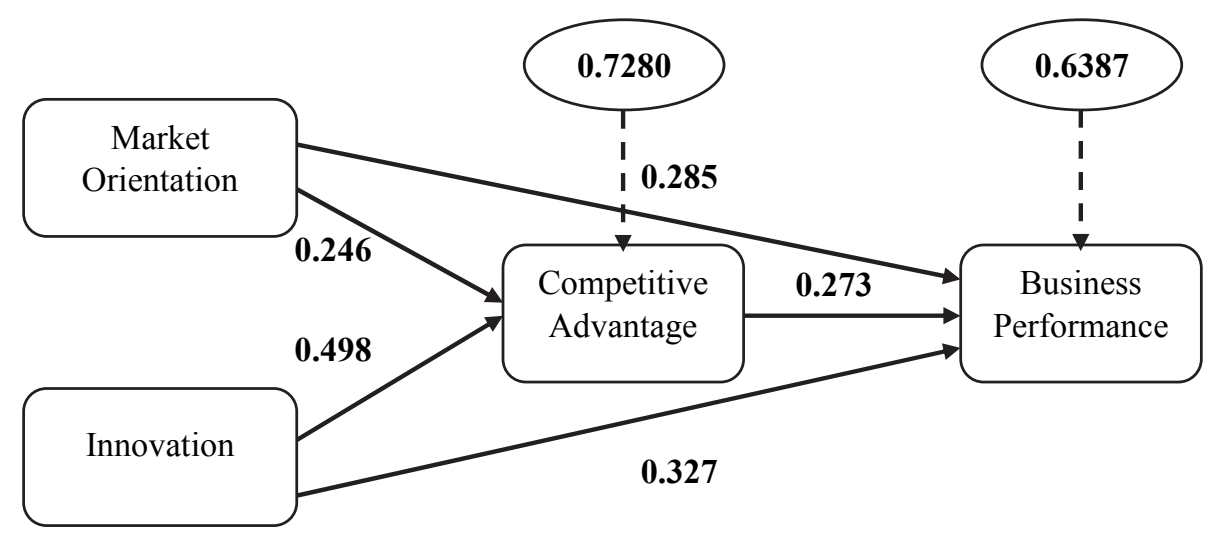

Fig. 1. The Structural Model Influence of Path Analysis

\subsection{Hypothesis Test}

To test the hypotheses of this survey, we use $t$ test or partial test. If the $t$ count $>\mathrm{t}$ from the standard table, then the hypothesis is accepted, which means there is a significant relationship between the independent variable and the dependent variable. The value of $t$ table is obtained from the $t$-student distribution with a significance level of 5\% (0.05) one tail and $d f=147$ for the model equation 1 is 1.65529 , and $d f=146$ for the model equation 2 is 1.65536 where $d f=n-k, n=$ total sample, $k=$ total variable.

Table 9

The results of $\mathrm{t}$-value for testing the hypotheses of the survey

\begin{tabular}{|c|c|c|c|c|}
\hline Hypothesis & Description & T count & T table & Conclusion \\
\hline $\mathrm{H}_{1}$ & Market orientation to competitive advantage & 3.083 & 1.65529 & Accepted \\
\hline $\mathrm{H}_{2}$ & Innovation to competitive advantage & 6.249 & 1.65529 & Accepted \\
\hline $\mathrm{H}_{3}$ & Market orientation to business performance & 3.935 & 1.65536 & Accepted \\
\hline $\mathrm{H}_{4}$ & Innovation to business performance & 4.141 & 1.65536 & Accepted \\
\hline $\mathrm{H}_{5}$ & Competitive advantage to business performance & 3.754 & 1.65536 & Accepted \\
\hline
\end{tabular}

Source: Processed primary data from SPSS, 2018

As we can observe from the results of Table 9, market orientation (MO) and innovation (IN) have positive impacts on competitive advantage (CA). Moreover, market orientation (MO), innovation (IN), and competitive advantage (CA) have maintained positive impact on business performance (BP).

\section{Discussion}

The effect of Market Orientation and Innovation on Competitive Advantage is $46.3 \%$. The influence of Market Orientation, Innovation, and Competitive Advantage on Business Performance is 58.4\%. Based on the descriptive analysis, Market Orientation and Innovation of textile SMEs in Selangor, Malaysia are in a moderate level and tend to approach a high level, with an average of 3.85 for Market Orientation and 3.83 for Innovation. Competitive Advantage is also at a moderate level and tends to approach high levels with an average of 3.79, while Business Performance has an average value of 3.87 which is also at a moderate level and tends to approach high levels.

Market orientation has a positive and significant effect toward competitive advantage in textile SMEs in Selangor, Malaysia. The results are consistent with the results of other studies conducted by Zhou et al. (2009), Kamya et al. (2010), Safarnia et al. (2011), Afsharghasemi, (2013), Talaja (2017), and Herman et al. (2018). Inter-functional coordination is an indicator with the lowest value compared with other indicators. Therefore, the owners or managers of textile SMEs can improve and synergize coordination between functions or between divisions that exist in SMEs, especially in the marketing division. Then, 
referring to the indicators of customer orientation and competitor orientation also still need attention and need to be improved again by focusing more on fulfilling what the customer wants, and making marketing programs more attractive than competitors.

Directly, Innovation has a positive and significant influence on the competitive advantage of textile SMEs in Selangor, Malaysia. The result is in line with the results from Wingwon (2012), Vazquez-avila (2014), Aziz, \& Samad (2016), and Kamboj \& Rahman (2017), and Herman et al. (2018). In product innovation, innovating new products that have never been on the market is less considered, so SME textile owners and managers need to improve the innovation. Increase product variation, make products that are unique and different from competitors, and make product packaging more attractive and they are also necessary for product development. In process innovation, textile SMEs need to increase innovation for example by using the latest methods and tools that are more effective and efficient that can increase productivity.

Competitive advantage as a mediating variable in this research direction has a positive and significant influence on business performance. The results are supported by the previous studies such as Lakhal (2009), Agha et al. (2011), Monsur \& Yoshi (2012), Talaja et al. (2017), and Herman et al. (2018). The competitive advantage of textile SMEs in Selangor, Malaysia seems to be in good shape, but some things need to be improved, such as the new production process, the new ideas on modifying products and marketing. In terms of differentiation, textile SMEs need to have a brand image that is different from competitors, have better advertising and promotion, and make customers easy to remember the products. In low-cost leadership, still we need to improve different issues such as producing in large quantities and using efficient processes to reduce costs and manage advertising costs wisely.

Market orientation has a positive effect toward business performance in textile SMEs in Selangor, Malaysia, both directly and indirectly. This result is in line with the result of Dubihlela and Sandada (2014), Š́lyová et al. (2015), Lee et al. (2015), Beneke et al. (2016), Amin et al. (2016), Buli (2017), Talaja et al. (2017), and Herman et al. (2018). Innovation has a positive and significant effect on business performance in textile SMEs in Selangor, Malaysia, both directly and indirectly. This result is in line with the results from Najib and Kiminami (2011), Saunila (2014), Vazquez-avila (2014), Amin et al. (2016), and Herman et al. (2018). In business performance, textile owners and managers of SMEs can pay more attention on market orientation in order to increase market performance. Furthermore, SMEs must strengthen good relations with suppliers, because suppliers can help SMEs in maintaining business performance by having suitable and sufficient material availability.

\section{Conclusion and Managerial Implications}

This study has provided an empirical investigation to determine the effects of market orientation and innovation toward competitive advantage and business performance of textile SMEs in Selangor, Malaysia. Market orientation and innovation partially have positive effects on the competitive advantage. This denotes that if the market orientation rises, the competitive advantage and innovation will also increase. Moreover, if innovation rises then the competitive advantage will also increase, and vice versa. Market orientation and innovation partially have positive and significant influences on business performance, both directly and indirectly mediated by competitive advantage. This means that if the market orientation increases, business performance will also increase. Likewise, if innovation increases, business performance will also increase. Competitive advantage as the mediating variable in this research partially has a positive and significant influence on the business performance of textile SMEs in Selangor, Malaysia

The results of the research may offer some implications, theoretically and practically. In terms of theoretical implication, the findings of this study will add value to the knowledge and understanding in details on how textile SMEs in Selangor, Malaysia can reach the competitive advantage and business performance through market orientation and innovation and, practically, the implication for owner and manager of textile SMEs especially in Selangor, Malaysia, since some things need to be improved. As recommended in the discussion, the results of this study provide several ways to improve business performance to be better. Owners and managers of textile SMEs can improve and optimize business performance 
again by increasing market orientation and innovation which will influence the increasing competitive advantage and business performance.

Limitation in this study comes from resources, such as time, energy, and costs. If costs do not limit this research, it may be possible to do research with more extensive and broader data, add samples, and increase respondents. It is expected that from this research there would be more researchers interested in research with this topic. Researchers who will examine the same topic with this research can deepen research so that more understanding of this topic will be gained. Adding to other factors that might influence competitive advantage and business performance needs to be accomplished to complement what already exists in this study. Furthermore, the results of this study and other future studies are expected to be able to help stakeholders for managerial decisions.

\section{References}

Afsharghasemi, A., Zain, M., Sambasivan, M., \& Imm, S. N. S. (2013). Market orientation, government regulation, competitive advantage and internationalization of SMEs: A study in Malaysia. Journal of Business Administration Research, 2(2), 13.

Agha, S., Alrubaiee, L., \& Jamhour, M. (2012). Effect of core competence on competitive advantage and organizational performance. International Journal of Business and management, 7(1), 192.

Amin, M., Thurasamy, R., Aldakhil, A. M., \& Kaswuri, A. H. B. (2016). The effect of market orientation as a mediating variable in the relationship between entrepreneurial orientation and SMEs performance. Nankai Business Review International, 7(1), 39-59.

Andriyanto, F., \& Sufian, M. S. (2017). Analisis Pengaruh Orientasi Pasar Dan Inovasi Terhadap Keunggulan Bersaing Dalam Rangka Meningkatkan Kinerja Bisnis. Fakultas Ekonomika dan Bisnis, Universitas Diponegoro.1-20.

ASEAN Statistic. (2018). Asean Trading Statistic. Retrieved March 2018, from https://data.aseanstats.org/trade

Azam, S. M. F., Haque, A., Sarwar, A., \& Anwar, N. (2014). Training Program Effectiveness of Service Initiators: Measuring Perception of Female Employees of Bank Using Logistic Approach. Asian Research Journal of Business Management, 1(2), 98-108.

Aziz, N. N. A., \& Samad, S. (2016). Innovation and competitive advantage: Moderating effects of firm age in foods manufacturing SMEs in Malaysia. Procedia Economics and Finance, 35, 256-266.

Beneke, J., Blampied, S., Dewar, N., \& Soriano, L. (2016). The impact of market orientation and learning orientation on organisational performance: A study of small to medium-sized enterprises in Cape Town, South Africa. Journal of Research in Marketing and Entrepreneurship, 18(1), 90-108.

Buli, B. M. (2017). Entrepreneurial orientation, market orientation and performance of SMEs in the manufacturing industry: Evidence from Ethiopian enterprises. Management Research Review, 40(3), 292-309.

Bulankulama, S.W.G.K., Khatibi, A. (2014). A Theoretical Approach to the Competitive Advantage Moderating Effects of Strategies; Innovation and IT. International Journal of Science and Research, 3(6), 1817-1820

Dubihlela, J., \& Sandada, M. (2014). Impact of strategic planning on small and medium-sized enterprises'(SMEs) performance: The role of employee participation, implementation incentives and evaluation and control. Journal of Economics, 5(1), 45-55.

Herman, Hendry., Hady, Hamdy., \& Arafah, Willy. (2018). The influence of market orientation and product innovation on the competitive advantage and its implication toward Small and Medium Enterprises (UKM) performance. International Journal of Science and Engineering Invention, 4(8).

Ismail, R., Tarofder, A. K. (2015). Corporate governance structure and firm performance in Small and Mediumsized enterprises (SMEs) in Sri Lanka: a path to access the credit. Journal of Management, 12(1), 28-37.

Kamboj, S., \& Rahman, Z. (2017). Market orientation, marketing capabilities and sustainable innovation: The mediating role of sustainable consumption and competitive advantage. Management Research 
Review, 40(6), 698-724.

Kamya, M. T., Ntayi, J. M., \& Ahiauzu, A. (2010). Knowledge management and competitive advantage : The interaction effect of market orientation. African Journal of Business Management, 4(14), 2971-2980.

Lakhal, L. (2009). Impact of quality on competitive advantage and organizational performance. The Journal of the Operational Research Society, 60(5), 637-645.

Lee, Y. K., Kim, S. H., Seo, M. K., \& Hight, S. K. (2015). Market orientation and business performance: Evidence from franchising industry. International Journal of Hospitality Management, 44, 28-37.

Malaysian Investment Development Authority. (2018). Textile and Textile Products. Retrieved August 2018, from http://www.mida.gov.my/home/textiles-and-textile-products/posts/?lg=MAL

Maydeu-Olivares, A., \& Lado, N. (2003). Market orientation and business economic performance: A mediated model. International Journal of Service Industry Management, 14(3), 284-309.

Ministry of International Trade and Industry Malaysia. (2015). Responses to NGOs on Free Trade Agreements (FTAs). Retrieved March 2019, from https://www.miti.gov.my/index.php/pages/view/2206

Ministry of International Trade and Industry Malaysia. (2017). Textile, Apparel footwear industry profile. Retrieved March 2018, from http:/www.miti.gov.my/miti/resources/4. Textile Apparel and Footwear Industry

Monsur, S. M. T., \& Yoshi, T. (2012). Improvement of firm performance by achieving competitive advantages through vertical integration in the apparel Shah Moahmmad Tanvir Monsur 1. Asian Economic and Financial Review, 2(6), 687-712.

Najib, M., \& Kiminami, A. (2011). Innovation, cooperation and business performance. Journal of Agribusiness in Developing and Emerging Economies, 1(1), 75-96. doi:10.1108/20440831111131523

Narver, J. C., \& Slater, S. F. (1990). narver and slatter.pdf. Journal of Marketing, (October 1990), 2035.

Nur, S., Zulkiffli, A., \& Perera, N. (2011). A literature analysis of business performance for SMEs subjective or objective measures? SIBR Conference on Interdisciplinary Business and Economics Research, 1-9.

Rahman, N., Othman, M., Yajid, M., Rahman, S., Yaakob, A., Masri, R., ... \& Ibrahim, Z. (2018). Impact of strategic leadership on organizational performance, strategic orientation and operational strategy. Management Science Letters, 8(12), 1387-1398.

Reniati (2013). Kreativitas Organisasi dan Inovasi Bisnis. Bandung: Alfabeta.

Rosli, M. M., \& Sidek, S. (2013). The impact of innovation on the performance of small and medium manufacturing enterprises : Evidence from Malaysia. Journal of Innovation Management in Small \& Medium Enterprise, 2013, 1-16. https://doi.org/10.5171/2013.885666

Safarnia, H., Akbari, Z., \& Abbasi, A. (2011). Review of market orientation \& competitive advantage in the industrial estates companies (Kerman, Iran): appraisal of model by Amos Graphics. World Journal of Social Sciences, 1(5), 132-150.

Šályová, S., Táborecká, J., Nedelová, G., \& Jaroslav, Ď. (2015). Effect of marketing orientation on business performance: A study from Slovak foodstuff industry. Procedia Economics and Finance, $34(15), 622-629$.

Saunila, M. (2014). Innovation capability for SME success: perspectives of financial and operational performance. Journal of Advances in Management Research, 11(2), 163-175.

Sekaran, U., \& Bougie, Roger. (2016). Research Methods for Business. (7th Ed.). West Sussex, United Kingdom: John Wiley \& Sons.

SME Corporation Malaysia. (2018). Retrieved March 2018, from http://www.smecorp.gov.my/index.php/en/policies/2015-12-21-09-09-49/sme-statistics

Smith, T. M., \& Reece, J. S. (1999). The relationship of strategy, fit, productivity, and business performance in a services setting. Journal of Operations Management, 17(2), 145-161.

Suriyapperuma, H. P., Ab Yajid, M. S., Khatibi, A., \& Premarathne, S. P. (2015). The Impact of Internet Adoption on SME performance in Sri Lanka: Development of a Conceptual Framework. International Journal of Arts and Commerce, 4(1), 46-58. 
Suriyapperuma, H. P., Yajid, M. S. A., Khatibi, A. (2015). The Impact of Business Networking on SME Performance: Development of a Conceptual Framework. International Journal of Management Sciences and Business Research, 4(2), 40-53.

Talaja, A., Miočević, D., Pavičić, J., \& Alfirević, N. (2017). Market orientation, competitive advantage and business performance: Exploring the indirect effects. Društvena istraživanja, 26(4), 583-604.

Tham, J., Ab Yazid, M. S., Khatibi, A. A., \& Azam, S. F. (2017). Internet and data security-understanding customer perception on trusting virtual banking security in Malaysia. European Journal of Social Sciences Studies, 2 (7), 186-207

Vazquez-avila, G. (2014). Innovation as Competitiveness Key Factor : SMEs Manufacturing Industry in Innovation as Competitiveness Key Factor: SMEs Manufacturing Industry in Guadalajara, Mexico.

Wingwon, B. (2012). Effects of entrepreneurship, organization capability, strategic decision making and innovation toward the competitive advantage of SMEs enterprises. Journal of Management \& Sustainability, 2, 137.

Zhou, K. Z., Brown, J. R., \& Dev, C. S. (2009). Market orientation, competitive advantage, and performance: A demand-based perspective. Journal of Business Research, 62(11), 1063-1070.

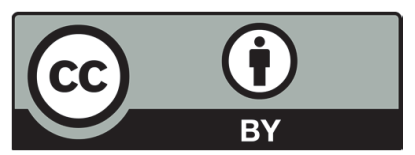

(C) 2019 by the authors; licensee Growing Science, Canada. This is an open access article distributed under the terms and conditions of the Creative Commons Attribution (CCBY) license (http://creativecommons.org/licenses/by/4.0/). 